\title{
Study and Practice on Distinctive Characteristics of Mechanical and Electrical Equipment Maintenance and Management Major in Guangzhou Railway Polytechnic \\ Qingcai Liu, Xuechun Wan \\ School of Mechanical and Electrical Engineering, Guangzhou Railway Polytechnic, Guangzhou, China
}

\section{ABSTRACT}

The construction of specialty characteristics shall start from the overall characteristics of the school, take the specialty group as the perspective, find the characteristic construction direction in the whole industrial chain, and improve the connotation of specialty. To promote the development of the specialty of mechanical and electrical equipment maintenance and management in domestic polytechnics, taking the construction process of this specialty in Guangzhou Railway polytechnic as an example, it was discussed on why and how to carry out the construction of major characteristics with the main line of the equipment maintenance of rail transit stations and train vehicle repair plants. Aspects were discussed including the establishment of curriculum system, the construction of specialty teachers' team, the construction of teaching software and hardware resources and the monitoring of teaching quality. The results can be used for reference in the construction of similar specialties in China. Keywords:

Major Characteristics, Major Positioning, Curriculum System, Vocational Education, Major Construction, Equipment Maintenance

\section{Introduction}

At present, with the beginning of featured major construction, the domestic polytechnics have gradually entered the stage of connotation promotion from the scale expansion (Chen, Pan, \& Chen, 2019; Huang, 2019; He, 2016). To meet the needs of local development, the major of mechanical and electrical equipment maintenance and management shall also promote its connotation. The main purpose of connotation promotion is to improve the quality of talent training. However, the talent training in polytechnics has been carried out by specific majors, so improving the quality of talent training is bound to improve the quality of talent training in each major. It is a systematic project to improve the quality of talent training, involving major positioning and characteristics, curriculum system, specialty teachers, teaching hardware such as training facilities and other resources, teaching software such as textbooks, online open courses and other resources, cooperation between school and enterprises, student management and so on. Among them, the construction of specialty characteristics plays a leading role in talent training. If a major finds its own orientation accurately, it will have a basis to carry out specialty construction, and the major will have vitality and soul, and eventually form its own distinct characteristics, which will obviously promote the quality of talent training. Therefore, the construction of specialty characteristics plays an important role in the quality of talent training. The Department of Education of Guangdong Province 
started to promote the construction of major with distinct characteristics in 2015, and thereafter changed the selected characteristic specialty into brand specialty construction in 2016. Its internal logic is that only the specialty with distinctive characteristics can more fit the needs of regional economic development, and can have good social influence and recognition, that is, brand effect.

The research and practice of distinct major characteristics and major brands have been more carried out in China. For example, in the construction of industrial design specialty in Zhejiang Agricultural and Forestry University, according to the regional industrial characteristics and specialty advantages of the school, the specialty characteristics focused on bamboo and wood industry was proposed. Starting from the construction of curriculum system, practical training, teachers and extracurricular learning resources, the construction of major characteristics has achieved remarkable results (Chen, Pan, \& Chen, 2019). The automobile marketing and service major of Guangdong Mechanical and Electrical Polytechnic, through skill competition to guide and promote the construction of high-level specialty, with mixed ownership as the carrier to explore cooperative education between the school and enterprise, with innovation and entrepreneurship projects into the classroom as the starting point to cultivate marketing talents and other means, has formed its own major characteristics (Huang, 2019). Some researches (He, 2016) think that the construction of talent training program is the key point of higher vocational education reform, and they discussed the background of personnel training of mechanical and electrical equipment maintenance and management major in polytechnics and put forward the construction program of corresponding training program, hoping to realize the seamless connection between school and enterprises. Some researchers discussed the construction planning and implementation plan of the major of mechanical and electrical equipment maintenance and management from four aspects: major characteristics and advantages, major positioning and construction objectives, construction content and implementation plan, and expected benefits (Yan, 2019). Some researchers believe that the construction of brand specialty is the core of the development of vocational education, and is the focus and breakthrough to promote the connotation development of polytechnics, can improve the level of school running, and the social reputation (Shi, 2009). According to the major teachers of environmental protection in Yangling Polytechnic, it is the starting point and foothold of major construction to rely on the local industry to carry out major construction and highlight the characteristics (Zhu, 2019). In the process of major construction, how to highlight major characteristics, avoid homogenization, and enhance the core competitiveness of the major is the first problem to be solved in the construction of major connotation.

On the whole, it is a basic consensus to find a foothold for the construction of specialty characteristics in the links of the industrial chain in connection with needs of local industry. In the literature, there are few discussions on the characteristic construction of the major of mechanical and electrical equipment maintenance and management, and the existing research is not comprehensive and superficial. However, the overall construction level of domestic mechanical and electrical equipment maintenance and management specialty lags behind, and theoretical research needs to be deepened. In order to promote the development of this major in China, it is necessary to make a detailed and in-depth study on the construction of its major characteristics.

\section{Connotation of Specialty Characteristics}

\subsection{Theoretical Perspective}


The characteristic is the style and form that make one thing or one kind of things distinct from other things. It is determined by the specific environmental factors on which things come into being and develop. Characteristics are unique to the things they belong to. The characteristics of things are mainly manifested in the following three aspects: the first one is "others do not have what I own", that is, uniqueness or individuality; the second one is "others do not have advantages of what I own", that is, outstanding or high-quality; the third one is "what others own although is good, but not as new as what I own", that is, openness or innovation.

\subsection{Specialty Perspective}

From the perspective of specialty, the specialty with distinctive characteristics refers to the specialty with sufficient personality gradually formed under the guidance of specific construction concept and in the long-term construction practice process. The specialty with distinct characteristics should reflect the school's orientation and characteristics to a certain extent, and have distinct characteristics in one or several aspects such as specialty construction concept, goal orientation, curriculum system, training mode, teaching resource conditions, teaching management, etc., with high construction level and talent training quality. Characteristic specialty is generally recognized by the society and has a high social reputation. In fact, it is also the major construction effect and goal of higher vocational colleges (Tan, 2017). It is beneficial to improve the quality of professional personnel training and enhance the ability of professional services to regional economic and social development through the construction of characteristic specialties. It is beneficial to form a demonstration leading role and drive the construction and development of other specialties in polytechnics. It is also beneficial to optimize the major structure of polytechnics and enhance their overall school running strength, vitality, influence and competitiveness. Thus, it can show the vitality of running a school with distinctive major characteristics, mark the level with characteristics, and prove the quality with characteristics.

The template is used to format your paper and style the text. All margins, column widths, line spaces, and text fonts are prescribed; please do not alter them. You may note peculiarities. For example, the head margin in this template measures proportionately more than is customary. This measurement and others are deliberate, using specifications that anticipate your paper as one part of the entire journals, and not as an independent document. Please do not revise any of the current designations.

\section{Causes and Process of the Lagging Construction of Mechanical and Electrical Equipment Maintenance and Management Specialty}

\subsection{Analysis on the Problems and Causes of Major Construction}

Because of the short starting time, the characteristic construction of domestic mechanical and electrical equipment maintenance and management specialty is still in the exploratory stage, the development state of the specialty is not ideal, and the number of polytechnics setting up the specialty has been decreasing. For example, there were 12 Vocational Colleges in Guangdong province to recruit students for this major, which has now been reduced to about 10 . The basic reason lies in the lack of characteristics and brand effect, and the low degree of social recognition leads to the difficulty of enrollment. Further analysis can be found that because of the large 
number of domestic industries and the wide range of mechanical and electrical equipment, most of the domestic mechanical and electrical equipment maintenance and management majors are often not able to accurately locate the direction of the major, which leads to the fact that the professional courses in the curriculum system of the major are only professional basic courses, unable to offer professional courses for a specific equipment, which does not meet the requirements of vocational education. Because the positioning of the major is not clear, the curriculum system, curriculum, teaching materials and training resources constructed will lose their pertinence, and the connection between the major and regional industry will be loose, which will not form the characteristics of the major.

The main body of characteristic construction is teachers of the major. From the perspective of institutional mechanism or interest mechanism, the characteristic reform of the major is inevitably restricted by the environment in which the teachers themselves live, which objectively affects the enthusiasm of teachers. Because of the heavy burden of teaching in higher vocational colleges, the assessment of teachers' workload is based on the number of hours of completed teaching courses, and the reform of the specialty's characteristic positioning involves the reconstruction of the curriculum system, which requires teachers to give up the familiar courses and reopen new courses. This requires teachers to relearn and organize teaching resources, which objectively increases the workload of teachers. Most teachers instinctively resist the reform of the major and prefer to stick to the old ways. If the management department can't understand and accept the specialty characteristic orientation, and the specialty characteristic reform can't get enough resource support, then the specialty reform is bound to be more difficult.

\subsection{Construction History of the Major}

During the construction of the major of mechanical and electrical equipment maintenance and management in Guangzhou railway Polytechnic, it has also experienced the process from no clear characteristic positioning, to non-specific machinery manufacturing industry, to rail transit repair and maintenance industry. At first, due to the limitation of teaching teachers and teaching resources, the curriculum system of this major is basically the same as that of mechatronics, and there is no curriculum system of its own. Later, with the gradual arrival of teachers and the gradual enrichment of teaching resources, it began to build its own curriculum system, but it did not respond to the overall characteristics of the school, did not find the micro positioning of the major from the macro characteristics of the school, and did not make full use of the cluster advantages of the school's many railway majors. With the accumulation of construction experience, the specialty began to consider, based on the overall positioning of the railway industry of the school, to find the specialty's own positioning and characteristic construction ideas, and began to build a curriculum system with its own characteristics.

\section{Practice of Specialty Characteristic Construction}

\subsection{Determination of Specialty Characteristic Orientation}

The specialty characteristic orientation must consider the construction of specialty group, that is to say, which specialty group the specialty belongs to and its position in the specialty group. There are two ways to build a major group, one is to build a major group based on the internal relations of each production link of the industrial chain, and the other is to build a specialty group according to the operation characteristics (Shi, 2010; Hu, 2019). The major groups shall be related to the 
similar technical fields or professional disciplines and professional posts, and one or more related majors in the school have achieved great construction results and distinctive features, which can drive the common development of other majors.

Guangzhou Railway Polytechnic is the only vocational college in Guangdong province with distinctive characteristics serving the rail transit industry. It adapts to the needs of large-scale and rapid construction and development of South China rail transit industry, because its rail transit characteristics have a certain social impact in South China. The traditional main major groups of the school cover the train vehicle maintenance, driving, operation, rail power supply, rail transit signal and other aspects of rail transit vehicles, and have formed respectively own major characteristics and influence. From the perspective of the whole industrial chain, the equipment covered by the above-mentioned major groups is mainly the equipment on the rail transit line, which does not cover a large number of mechanical and electrical equipment supporting the rail transit system, such as stations, depots, vehicle repair plants, etc., while the operation and maintenance of these equipment requires a large number of talents with solid theory and skills, and the required number is about $10 \%-20 \%$ of the number of vehicle maintenance personnel. Take a subway line as an example, about 30 - 40 people, depending on the number of vehicles. From the perspective of coordination of major groups, on the one hand, the major of mechanical and electrical equipment maintenance and management can make full use of the advantages brought by the major groups, and expand the coverage of talent cultivation in the rail transit industry chain in the macro characteristic category of the school. On the other hand, it finds the major development space, adapts to the needs of the rail transit industry for mechanical and electrical equipment maintenance talents, realizes the dislocation development with the original track specialty of the school, and improves the support for the school's characteristics.

\subsection{Construction of Curriculum System of the Major}

It is necessary to build a curriculum system corresponding to the specialty orientation in order to implement the specialty orientation into a practical scheme. To establish the curriculum system, we need to arrange the professional courses and basic courses of equipment maintenance according to the corresponding positions of the target equipment to be maintained. The course arrangement should also consider the needs of the post group of the students' future career development path. See Table 1 for the main professional post groups of students.

The types of equipment used in rail transit stations are diverse and complex, including electronic equipment, power supply equipment, air conditioning equipment, firefighting equipment, security equipment, elevator equipment, water supply and drainage equipment, signal equipment, train operation equipment, etc. one or more of them must be selected as the main direction of professional personnel training. A variety of electronic equipment in the above-mentioned

Table 1. Career development path post group of students.

equipment are generally covered by electronic technology specialty, signal equipment and train operation equipment are covered by railway signal specialty, railway operation specialty, electronic specialty, electromechanical integration specialty, computer specialty, and security equipment are covered by electromechanical integration specialty and electronic technology specialty. However, air conditioning equipment, firefighting equipment, water supply and drainage equipment and elevator equipment have their own professional coverage according to the traditional specialty classification in China, but the problem is that 
the maintenance workload of these single types of equipment is insufficient at ordinary times. According to the traditional major classification, personnel allocation is obviously unreasonable in economy, resulting too many personnel allocation, and does not meet the requirements of enterprise. What rail transit stations need is personnel who can manage air conditioning, elevator, firefighting and water supply and drainage at the same time. Such personnel allocation is only a fraction of the traditional allocation, which can greatly reduce the cost of personnel. Therefore, the air conditioning, firefighting, water supply and drainage, elevator equipment of the above rail station are the learning contents of the major of mechanical and electrical equipment maintenance and management, and the curriculum system was arranged and constructed accordingly. The curriculum system was shown in Figure 1.

As shown in Figure 1, the curriculum system consists of three parts: public basic courses, major basic courses and major courses. Public basic module is divided into public basic and public elective module.

The public basic course module is a general education module, which is designated by the school and must be completed by all students in any major. As the expansion of general knowledge, the public elective module allows students to choose other general courses in addition to the three courses of quality expansion, practical writing, and college students' mental health education. The total

Figure 1. Schematic diagram of the curriculum system.

credits of the courses selected by students shall be no less than 4 credits. Major basic modules are divided into three parts: mechanical module, electrical module, and centralized practical skills training module. The composition of major courses includes two parts: major courses and major elective courses. The major courses mainly include the maintenance of station firefighting and water supply and drainage system, the maintenance of station air conditioning and ventilation system, the maintenance of station elevator, maintenance equipment and engineering vehicles in rail transit vehicles depot, the maintenance of general mechanical equipment, and graduation post internship. The major courses mainly focus on the maintenance of equipment in rail transit stations, while the maintenance of general mechanical equipment mainly teaches the general mechanical equipment used in stations and vehicle factories, such as crane, pumps, centrifugal fans and air compressors. Maintenance equipment and engineering vehicles of rail transit vehicles depot mainly teach the principle and maintenance of main process equipment of vehicle repair factory. Graduation post internship is arranged in the last semester of school.

Major selective module courses are designed to supplement or expand the possible deficiencies or weaknesses of specific positions in vehicle repair plants or station equipment maintenance. Students must choose one of three modules to study.

\subsection{Construction of Teaching Resources}

In order to effectively implement the curriculum system, the required software and hardware resources must be established. Hardware resources mainly include basic mechanical and electrical training equipment, mechanical transmission unit, crane, fan, water pump and air compressor and other general equipment, surveying and mapping equipment, machining equipment, electrician qualification examination equipment, station air conditioning and ventilation equipment, station fire and water supply equipment, elevator, hydraulic and pneumatic training equipment, PLC and single-chip microcomputer. Post specific training is mainly carried out in rail transit equipment repair and manufacturing enterprises, so a number of off-campus enterprise practice bases should be established to meet the requirements of students' practice. 
Software resources are mainly the construction of network courses, outsourcing PLC, single-chip microcomputer, equipment management and other software. The mature online courses are open to the public. Relying on the above online courses and mooc courses, the traditional classroom teaching method can be reformed, giving students more autonomy and initiative in learning. It is convenient for students to preview before class and review after class, accept more exercises and examinations, and improve the effectiveness of teaching.

\subsection{Teachers of the Major}

Teachers are the key to the implementation of the above curriculum system. The teachers of this major are arranged according to the requirements of the above curriculum system. Teachers are required to have a master's degree or above, at least 3 years of practical technical work experience in rail transit enterprises. Teachers of this major shall have more than 2 weeks' working experience in a rail transit enterprise every year. The work can take the form of participating in the technical work of the enterprise, leading students to work as interns in the enterprise, and training the employees of the enterprise. By participating in or observing the actual production process in the enterprise, teachers can timely understand and master the technology application status and technology progress. Teachers are required to listen to each other and discuss the common problems in teaching.

The part-time teacher hired from the enterprise should be engaged in the actual technical work of the enterprise corresponding to the curriculum. Part-time teachers should be mainly engaged in the teaching of professional courses. They may be responsible for the teaching of the whole course, several chapters, or lectures on a technical issue. Part-time teachers who are engaged in practical training courses should have strong practical ability or have enough on-the-spot practical experience, and their academic requirements can be reduced appropriately. The practical teaching process can be organized with the cooperation and guidance of teachers in the school.

\subsection{Teaching Quality Control}

In order to form a closed-loop system, teaching quality must be monitored in order to grasp the implementation effect and information feedback of the curriculum system. The principle of teaching quality control is the same as that of product quality control. Monitoring is carried out according to the principle of process control to ensure that all relevant links of teaching are under control. For example, during the teaching process, teachers should accept the spot check from the quality management department, check the actual teaching status, and timely give suggestions or rectification requirements. In every semester student forum shall also be arranged, so student representatives from random selection can comment on each course, give the students' opinions on the teacher's teaching situation. The students' attendance is strictly assessed and linked to the course results, and the students are urged to study hard. After the final exam papers are handed in, they will be subject to spot check and assessment to check the students' examination situation and the quality of the examination papers.

\subsection{Construction Effect}

In accordance with the above ideas and methods, the major of mechanical and electrical equipment maintenance and management has implemented the major transformation, with rail transit station as the main, vehicle repair and 
manufacturing factory as the auxiliary to redefine the direction of the major, gradually formed the distinctive characteristics of the major, promote the construction and development of the major. This major has become the only featured brand specialty of mechanical and electrical equipment maintenance and management recognized by the government of Guangdong province, and has cooperated with rail vehicles manufacturer to set up a modern apprenticeship class of rail transit equipment manufacturing and maintenance. In cooperation with other colleges and universities, we have carried out the construction of national professional teaching resources database, two courses were selected as the online open courses of Duangdong province and 7 textbook were published publicly, and we have presided over the compilation of national professional teaching standards for mechanical and electrical equipment maintenance and management.

\section{Conclusion}

The construction of major connotation must start with the construction of major characteristics, which need to consider the overall characteristics of the school, analyze the major positioning in the school major group, and look for the major positioning from the perspective of talent demand of the whole industry chain. In accordance with this idea, the major of mechanical and electrical equipment maintenance and management of Guangzhou Railway polytechnics has taken the maintenance of station and rail vehicle repair plants equipment in rail transit industry as the major orientation, carried out personnel training design, constructed the major curriculum system and teaching software and hardware resources, and carried out the construction of teaching staff. From the perspective of construction results, we have achieved the construction objectives, formed our own major characteristics, and improved the level of talent training.

Due to the large number of equipment in rail transit stations and vehicle repair plants, a single major cannot completely cover the maintenance of all equipment. This requires the integration of mechanical and electrical, urban rail transit mechanical and electrical technology, numerical control technology, machinery manufacturing and automation, application electronics and other disciplines to coordinate respective positioning and characteristics, carry out construction according to their own major characteristics, form dislocation development, and form a new professional cluster characteristic advantage.

\section{Acknowledgements}

This article was funded by the 2018 online open courses project of Guangdong Department of Education (Document No [2018]194 from Guangdong Department of Education).

\section{Conflicts of Interest}

The authors declare no conflicts of interest regarding the publication of this paper.

\section{Cite this paper}

Liu, Q. C., \& Wan, X. C. (2020). Study and Practice on Distinctive Characteristics of Mechanical and Electrical Equipment Maintenance and Management Major in Guangzhou Railway Polytechnic. Creative Education, 11, 513-523. https://doi.org/10.4236/ce.2020.114038 


\section{References}

Siayah, Syarofis; \& Setiawan, Adib Rifqi. (2020, April 13). A Brief Explanation of Science Education. EdArXiv. DOI: https://doi.org/10.35542/osf.io/2evn3

Siayah, Syarofis; \& Setiawan, Adib Rifqi. (2020, April 13). A Brief Explanation of Science Education. Thesis Commons. DOI: https://doi.org/10.31237/osf.io/wkvsn

Setiawan, Adib Rifqi; \& Ilmiyah, Surotul. (2020, April 13). Multiple Intelligences Based on Neuroscience. Thesis Commons. DOI: https://doi.org/10.31237/osf.io/e9fyu

Setiawan, Adib Rifqi; \& Ilmiyah, Surotul. (2020, April 13). Kecerdasan Majemuk Berdasarkan Neurosains. EdArXiv. DOI: https://doi.org/10.35542/osf.io/rj2fe

Setiawan, Adib Rifqi. (2020, April 9). Islamic Education in Southeast Asia. EdArXiv. DOI: https://doi.org/10.35542/osf.io/dnjqv

Ilmiyah, Surotul; \& Setiawan, Adib Rifqi. (2020, April 7). Students' Worksheet for Distance Learning Based on Scientific Literacy in the Topic Coronavirus Disease 2019 (COVID-19). Thesis Commons. DOI: https://doi.org/10.31237/osf.io/fpg4j

Ilmiyah, Surotul; \& Setiawan, Adib Rifqi. (2020, April 7). Students' Worksheet for Distance Learning Based on Scientific Literacy in the Topic Coronavirus Disease 2019 (COVID-19). EdArXiv. DOI: https://doi.org/10.35542/osf.io/wyz5v

Setiawan, Adib Rifqi; \& Ilmiyah, Surotul. (2020, April 7). Lembar Kegiatan Siswa untuk Pembelajaran Jarak Jauh Berdasarkan Literasi Saintifik pada Topik Penyakit Coronavirus 2019 (COVID-19). EdArXiv. DOI: https://doi.org/10.35542/osf.io/h4632

Setiawan, Adib Rifqi. (2020, April 2). Desain Pembelajaran untuk Membimbing Siswa Sekolah Dasar dalam Memperoleh Literasi Saintifik. EdArXiv. DOI: https://doi.org/10.35542/osf.io/u59f8

Velasufah, Whasfi; \& Setiawan, Adib Rifqi. (2020, April 13). Nilai Pesantren Sebagai Dasar Pendidikan Karakter. Thesis Commons. DOI: https://doi.org/10.31237/osf.io/hq6kz

Setiawan, Adib Rifqi. (2020, April 9). Islamic Education in Southeast Asia. Thesis Commons. DOI: https://doi.org/10.31237/osf.io/e794d

Setiawan, Adib Rifqi. (2020, April 2). What is the Best Way to Analyze Pre-Post Data?. EdArXiv. DOI: https://doi.org/10.35542/osf.io/h4e6q

Setiawan, Adib Rifqi. (2020, April 4). Grace Natalie Louisa. SocArXiv. DOI: https://doi.org/10.31235/osf.io/zwf6g

Setiawan, Adib Rifqi. (2020, April 3). Sharifah Halimah Alaydrus : a female preachers for our time. SocArXiv. DOI: https://doi.org/10.31235/osf.io/zb8qe

Setiawan, Adib Rifqi. (2020, April 1). Syarifah Halimah Alaydrus. Thesis Commons. DOI: https://doi.org/10.31237/osf.io/xbmcs 
Setiawan, Adib Rifqi. (2020, April 13). Commodification of the Sexuality in Kim Kardashian's Instagram Posts. Thesis Commons. URL: https://thesiscommons.org/mf7nw/

Setiawan, Adib Rifqi. (2020, April 5). The Arrogant One. Thesis Commons. DOI: https://doi.org/10.31237/osf.io/8nmku

Setiawan, Adib Rifqi. (2020, April 4). Grace Natalie Louisa. Thesis Commons. DOI: https://doi.org/10.31237/osf.io/u3mxv

Setiawan, Adib Rifqi. (2020, April 2). JUPE My Uncut Story. Open Science Framework (OSF). DOI: https://doi.org/10.31219/osf.io/qdxga

Setiawan, Adib Rifqi. (2020, April 1). Sharifah Halimah Alaydrus. Thesis Commons. DOI: https://doi.org/10.31237/osf.io/fp79c

Setiawan, Adib Rifqi. (2020, April 13). مبادئ اللغة العربية. Thesis Commons. DOI: https://doi.org/10.31237/osf.io/2gvjf

Siayah, Syarofis; \& Setiawan, Adib Rifqi. (2020, April 13). A Brief Explanation of Science Education. EdArXiv. DOI: https://doi.org/10.35542/osf.io/2evn3

Siayah, Syarofis; \& Setiawan, Adib Rifqi. (2020, April 13). A Brief Explanation of Science Education. Thesis Commons. DOI: https://doi.org/10.31237/osf.io/wkvsn

Setiawan, Adib Rifqi; \& Ilmiyah, Surotul. (2020, April 13). Multiple Intelligences Based on Neuroscience. Thesis Commons. DOI: https://doi.org/10.31237/osf.io/e9fyu

Setiawan, Adib Rifqi; \& Ilmiyah, Surotul. (2020, April 13). Kecerdasan Majemuk Berdasarkan Neurosains. EdArXiv. DOI: https://doi.org/10.35542/osf.io/rj2fe

Setiawan, Adib Rifqi. (2020, April 9). Islamic Education in Southeast Asia. EdArXiv. DOI: https://doi.org/10.35542/osf.io/dnjqv

Ilmiyah, Surotul; \& Setiawan, Adib Rifqi. (2020, April 7). Students' Worksheet for Distance Learning Based on Scientific Literacy in the Topic Coronavirus Disease 2019 (COVID-19). Thesis Commons. DOI: https://doi.org/10.31237/osf.io/fpg4j

Ilmiyah, Surotul; \& Setiawan, Adib Rifqi. (2020, April 7). Students' Worksheet for Distance Learning Based on Scientific Literacy in the Topic Coronavirus Disease 2019 (COVID-19). EdArXiv. DOI: https://doi.org/10.35542/osf.io/wyz5v

Setiawan, Adib Rifqi; \& Ilmiyah, Surotul. (2020, April 7). Lembar Kegiatan Siswa untuk Pembelajaran Jarak Jauh Berdasarkan Literasi Saintifik pada Topik Penyakit Coronavirus 2019 (COVID-19). EdArXiv. DOI: https://doi.org/10.35542/osf.io/h4632

Setiawan, Adib Rifqi. (2020, April 2). Desain Pembelajaran untuk Membimbing Siswa Sekolah Dasar dalam Memperoleh Literasi Saintifik. EdArXiv. DOI: https://doi.org/10.35542/osf.io/u59f8

Velasufah, Whasfi; \& Setiawan, Adib Rifqi. (2020, April 13). Nilai Pesantren Sebagai Dasar Pendidikan Karakter. Thesis Commons. DOI: https://doi.org/10.31237/osf.io/hq6kz 
Setiawan, Adib Rifqi. (2020, April 9). Islamic Education in Southeast Asia. Thesis Commons. DOI: https://doi.org/10.31237/osf.io/e794d

Setiawan, Adib Rifqi. (2020, April 2). What is the Best Way to Analyze Pre-Post Data?. EdArXiv. DOI: https://doi.org/10.35542/osf.io/h4e6q

Setiawan, Adib Rifqi. (2020, April 4). Grace Natalie Louisa. SocArXiv. DOI: https://doi.org/10.31235/osf.io/zwf6g

Setiawan, Adib Rifqi. (2020, April 3). Sharifah Halimah Alaydrus : a female preachers for our time. SocArXiv. DOI: https://doi.org/10.31235/osf.io/zb8qe

Setiawan, Adib Rifqi. (2020, April 1). Syarifah Halimah Alaydrus. Thesis Commons. DOI: https://doi.org/10.31237/osf.io/xbmcs

Setiawan, Adib Rifqi. (2020, April 13). Commodification of the Sexuality in Kim Kardashian's Instagram Posts. Thesis Commons. URL: https://thesiscommons.org/mf7nw/

Setiawan, Adib Rifqi. (2020, April 5). The Arrogant One. Thesis Commons. DOI: https://doi.org/10.31237/osf.io/8nmku

Setiawan, Adib Rifqi. (2020, April 4). Grace Natalie Louisa. Thesis Commons. DOI: https://doi.org/10.31237/osf.io/u3mxv

Setiawan, Adib Rifqi. (2020, April 2). JUPE My Uncut Story. Open Science Framework (OSF). DOI: https://doi.org/10.31219/osf.io/qdxga

Setiawan, Adib Rifqi. (2020, April 1). Sharifah Halimah Alaydrus. Thesis Commons. DOI: https://doi.org/10.31237/osf.io/fp79c

Setiawan, Adib Rifqi. (2020, April 13). مبادئ اللغة العربية. Thesis Commons. DOI: https://doi.org/10.31237/osf.io/2gvjf

Siayah, Syarofis; \& Setiawan, Adib Rifqi. (2020, April 13). A Brief Explanation of Science Education. EdArXiv. DOI: https://doi.org/10.35542/osf.io/2evn3

Siayah, Syarofis; \& Setiawan, Adib Rifqi. (2020, April 13). A Brief Explanation of Science Education. Thesis Commons. DOI: https://doi.org/10.31237/osf.io/wkvsn

Setiawan, Adib Rifai; \& Ilmiyah, Surotul. (2020, April 13). Multiple Intelligences Based on Neuroscience. Thesis Commons. DOI: https://doi.org/10.31237/osf.io/e9fyu

Setiawan, Adib Rifqi; \& Ilmiyah, Surotul. (2020, April 13). Kecerdasan Majemuk Berdasarkan Neurosains. EdArXiv. DOI: https://doi.org/10.35542/osf.io/rj2fe

Setiawan, Adib Rifqi. (2020, April 9). Islamic Education in Southeast Asia. EdArXiv. DOI: https://doi.org/10.35542/osf.io/dnjqv

Ilmiyah, Surotul; \& Setiawan, Adib Rifqi. (2020, April 7). Students' Worksheet for Distance Learning Based on Scientific Literacy in the Topic Coronavirus Disease 2019 (COVID-19). Thesis Commons. DOI: https://doi.org/10.31237/osf.io/fpg4j 
Ilmiyah, Surotul; \& Setiawan, Adib Rifqi. (2020, April 7). Students' Worksheet for Distance Learning Based on Scientific Literacy in the Topic Coronavirus Disease 2019 (COVID-19). EdArXiv. DOI: https://doi.org/10.35542/osf.io/wyz5v

Setiawan, Adib Rifqi; \& Ilmiyah, Surotul. (2020, April 7). Lembar Kegiatan Siswa untuk Pembelajaran Jarak Jauh Berdasarkan Literasi Saintifik pada Topik Penyakit Coronavirus 2019 (COVID-19). EdArXiv. DOI: https://doi.org/10.35542/osf.io/h4632

Setiawan, Adib Rifqi. (2020, April 2). Desain Pembelajaran untuk Membimbing Siswa Sekolah Dasar dalam Memperoleh Literasi Saintifik. EdArXiv. DOI: https://doi.org/10.35542/osf.io/u59f8

Velasufah, Whasfi; \& Setiawan, Adib Rifqi. (2020, April 13). Nilai Pesantren Sebagai Dasar Pendidikan Karakter. Thesis Commons. DOI: https://doi.org/10.31237/osf.io/hq6kz

Setiawan, Adib Rifqi. (2020, April 9). Islamic Education in Southeast Asia. Thesis Commons. DOI: https://doi.org/10.31237/osf.io/e794d

Setiawan, Adib Rifqi. (2020, April 2). What is the Best Way to Analyze Pre-Post Data?. EdArXiv. DOI: https://doi.org/10.35542/osf.io/h4e6q

Setiawan, Adib Rifqi. (2020, April 4). Grace Natalie Louisa. SocArXiv. DOI: https://doi.org/10.31235/osf.io/zwf6g

Setiawan, Adib Rifqi. (2020, April 3). Sharifah Halimah Alaydrus : a female preachers for our time. SocArXiv. DOI: https://doi.org/10.31235/osf.io/zb8qe

Setiawan, Adib Rifqi. (2020, April 1). Syarifah Halimah Alaydrus. Thesis Commons. DOI: https://doi.org/10.31237/osf.io/xbmcs

Setiawan, Adib Rifqi. (2020, April 13). Commodification of the Sexuality in Kim Kardashian's Instagram Posts. Thesis Commons. URL: https://thesiscommons.org/mf7nw/

Setiawan, Adib Rifqi. (2020, April 5). The Arrogant One. Thesis Commons. DOI: https://doi.org/10.31237/osf.io/8nmku

Setiawan, Adib Rifqi. (2020, April 4). Grace Natalie Louisa. Thesis Commons. DOI: https://doi.org/10.31237/osf.io/u3mxv

Setiawan, Adib Rifqi. (2020, April 2). JUPE My Uncut Story. Open Science Framework (OSF). DOI: https://doi.org/10.31219/osf.io/qdxga

Setiawan, Adib Rifqi. (2020, April 1). Sharifah Halimah Alaydrus. Thesis Commons. DOI: https://doi.org/10.31237/osf.io/fp79c

Setiawan, Adib Rifqi. (2020, April 13). مبادئ اللغة العربية. Thesis Commons. DOI: https://doi.org/10.31237/osf.io/2gvjf

Siayah, Syarofis; \& Setiawan, Adib Rifqi. (2020, April 13). A Brief Explanation of Science Education. EdArXiv. DOI: https://doi.org/10.35542/osf.io/2evn3 
Siayah, Syarofis; \& Setiawan, Adib Rifqi. (2020, April 13). A Brief Explanation of Science Education. Thesis Commons. DOI: https://doi.org/10.31237/osf.io/wkvsn

Setiawan, Adib Rifqi; \& Ilmiyah, Surotul. (2020, April 13). Multiple Intelligences Based on Neuroscience. Thesis Commons. DOI: https://doi.org/10.31237/osf.io/e9fyu

Setiawan, Adib Rifqi; \& Ilmiyah, Surotul. (2020, April 13). Kecerdasan Majemuk Berdasarkan Neurosains. EdArXiv. DOI: https://doi.org/10.35542/osf.io/rj2fe

Setiawan, Adib Rifqi. (2020, April 9). Islamic Education in Southeast Asia. EdArXiv. DOI: https://doi.org/10.35542/osf.io/dnjqv

Ilmiyah, Surotul; \& Setiawan, Adib Rifqi. (2020, April 7). Students' Worksheet for Distance Learning Based on Scientific Literacy in the Topic Coronavirus Disease 2019 (COVID-19). Thesis Commons. DOI: https://doi.org/10.31237/osf.io/fpg4j

Ilmiyah, Surotul; \& Setiawan, Adib Rifqi. (2020, April 7). Students' Worksheet for Distance Learning Based on Scientific Literacy in the Topic Coronavirus Disease 2019 (COVID-19). EdArXiv. DOI: https://doi.org/10.35542/osf.io/wyz5v

Setiawan, Adib Rifqi; \& Ilmiyah, Surotul. (2020, April 7). Lembar Kegiatan Siswa untuk Pembelajaran Jarak Jauh Berdasarkan Literasi Saintifik pada Topik Penyakit Coronavirus 2019 (COVID-19). EdArXiv. DOI: https://doi.org/10.35542/osf.io/h4632

Setiawan, Adib Rifqi. (2020, April 2). Desain Pembelajaran untuk Membimbing Siswa Sekolah Dasar dalam Memperoleh Literasi Saintifik. EdArXiv. DOI: https://doi.org/10.35542/osf.io/u59f8

Velasufah, Whasfi; \& Setiawan, Adib Rifqi. (2020, April 13). Nilai Pesantren Sebagai Dasar Pendidikan Karakter. Thesis Commons. DOI: https://doi.org/10.31237/osf.io/hq6kz

Setiawan, Adib Rifqi. (2020, April 9). Islamic Education in Southeast Asia. Thesis Commons. DOI: https://doi.org/10.31237/osf.io/e794d

Setiawan, Adib Rifqi. (2020, April 2). What is the Best Way to Analyze Pre-Post Data?. EdArXiv. DOI: https://doi.org/10.35542/osf.io/h4e6q

Setiawan, Adib Rifqi. (2020, April 4). Grace Natalie Louisa. SocArXiv. DOI: https://doi.org/10.31235/osf.io/zwf6g

Setiawan, Adib Rifqi. (2020, April 3). Sharifah Halimah Alaydrus : a female preachers for our time. SocArXiv. DOI: https://doi.org/10.31235/osf.io/zb8qe

Setiawan, Adib Rifqi. (2020, April 1). Syarifah Halimah Alaydrus. Thesis Commons. DOI: https://doi.org/10.31237/osf.io/xbmcs

Setiawan, Adib Rifqi. (2020, April 13). Commodification of the Sexuality in Kim Kardashian's Instagram Posts. Thesis Commons. URL: https://thesiscommons.org/mf7nw/

Setiawan, Adib Rifqi. (2020, April 5). The Arrogant One. Thesis Commons. DOI: https://doi.org/10.31237/osf.io/8nmku 
Setiawan, Adib Rifqi. (2020, April 4). Grace Natalie Louisa. Thesis Commons. DOI: https://doi.org/10.31237/osf.io/u3mxv

Setiawan, Adib Rifqi. (2020, April 2). JUPE My Uncut Story. Open Science Framework (OSF). DOI: https://doi.org/10.31219/osf.io/qdxga

Setiawan, Adib Rifqi. (2020, April 1). Sharifah Halimah Alaydrus. Thesis Commons. DOI: https://doi.org/10.31237/osf.io/fp79c

Setiawan, Adib Rifqi. (2020, April 13). مبادئ اللغة العربية. Thesis Commons. DOI: https://doi.org/10.31237/osf.io/2gvjf

Siayah, Syarofis; \& Setiawan, Adib Rifqi. (2020, April 13). A Brief Explanation of Science Education. EdArXiv. DOI: https://doi.org/10.35542/osf.io/2evn3

Siayah, Syarofis; \& Setiawan, Adib Rifqi. (2020, April 13). A Brief Explanation of Science Education. Thesis Commons. DOI: https://doi.org/10.31237/osf.io/wkvsn

Setiawan, Adib Rifqi; \& Ilmiyah, Surotul. (2020, April 13). Multiple Intelligences Based on Neuroscience. Thesis Commons. DOI: https://doi.org/10.31237/osf.io/e9fyu

Setiawan, Adib Rifqi; \& Ilmiyah, Surotul. (2020, April 13). Kecerdasan Majemuk Berdasarkan Neurosains. EdArXiv. DOI: https://doi.org/10.35542/osf.io/rj2fe

Setiawan, Adib Rifqi. (2020, April 9). Islamic Education in Southeast Asia. EdArXiv. DOI: https://doi.org/10.35542/osf.io/dnjqv

Ilmiyah, Surotul; \& Setiawan, Adib Rifqi. (2020, April 7). Students' Worksheet for Distance Learning Based on Scientific Literacy in the Topic Coronavirus Disease 2019 (COVID-19). Thesis Commons. DOI: https://doi.org/10.31237/osf.io/fpg4j

Ilmiyah, Surotul; \& Setiawan, Adib Rifqi. (2020, April 7). Students' Worksheet for Distance Learning Based on Scientific Literacy in the Topic Coronavirus Disease 2019 (COVID-19). EdArXiv. DOI: https://doi.org/10.35542/osf.io/wyz5v

Setiawan, Adib Rifqi; \& Ilmiyah, Surotul. (2020, April 7). Lembar Kegiatan Siswa untuk Pembelajaran Jarak Jauh Berdasarkan Literasi Saintifik pada Topik Penyakit Coronavirus 2019 (COVID-19). EdArXiv. DOI: https://doi.org/10.35542/osf.io/h4632

Setiawan, Adib Rifqi. (2020, April 2). Desain Pembelajaran untuk Membimbing Siswa Sekolah Dasar dalam Memperoleh Literasi Saintifik. EdArXiv. DOI: https://doi.org/10.35542/osf.io/u59f8

Velasufah, Whasfi; \& Setiawan, Adib Rifqi. (2020, April 13). Nilai Pesantren Sebagai Dasar Pendidikan Karakter. Thesis Commons. DOI: https://doi.org/10.31237/osf.io/hq6kz

Setiawan, Adib Rifqi. (2020, April 9). Islamic Education in Southeast Asia. Thesis Commons. DOI: https://doi.org/10.31237/osf.io/e794d

Setiawan, Adib Rifqi. (2020, April 2). What is the Best Way to Analyze Pre-Post Data?. EdArXiv. DOI: https://doi.org/10.35542/osf.io/h4e6q 
Setiawan, Adib Rifqi. (2020, April 4). Grace Natalie Louisa. SocArXiv. DOI: https://doi.org/10.31235/osf.io/zwf6g

Setiawan, Adib Rifqi. (2020, April 3). Sharifah Halimah Alaydrus : a female preachers for our time. SocArXiv. DOI: https://doi.org/10.31235/osf.io/zb8qe

Setiawan, Adib Rifqi. (2020, April 1). Syarifah Halimah Alaydrus. Thesis Commons. DOI: https://doi.org/10.31237/osf.io/xbmcs

Setiawan, Adib Rifqi. (2020, April 13). Commodification of the Sexuality in Kim Kardashian's Instagram Posts. Thesis Commons. URL: https://thesiscommons.org/mf7nw/

Setiawan, Adib Rifqi. (2020, April 5). The Arrogant One. Thesis Commons. DOI: https://doi.org/10.31237/osf.io/8nmku

Setiawan, Adib Rifqi. (2020, April 4). Grace Natalie Louisa. Thesis Commons. DOI: https://doi.org/10.31237/osf.io/u3mxv

Setiawan, Adib Rifqi. (2020, April 2). JUPE My Uncut Story. Open Science Framework (OSF). DOI: https://doi.org/10.31219/osf.io/qdxga

Setiawan, Adib Rifqi. (2020, April 1). Sharifah Halimah Alaydrus. Thesis Commons. DOI: https://doi.org/10.31237/osf.io/fp79c

Setiawan, Adib Rifqi. (2020, April 13). مبادئ اللغة العربية. Thesis Commons. DOI: https://doi.org/10.31237/osf.io/2gvjf

Siayah, Syarofis; \& Setiawan, Adib Rifqi. (2020, April 13). A Brief Explanation of Science Education. EdArXiv. DOI: https://doi.org/10.35542/osf.io/2evn3

Siayah, Syarofis; \& Setiawan, Adib Rifqi. (2020, April 13). A Brief Explanation of Science Education. Thesis Commons. DOI: https://doi.org/10.31237/osf.io/wkvsn

Setiawan, Adib Rifai; \& Ilmiyah, Surotul. (2020, April 13). Multiple Intelligences Based on Neuroscience. Thesis Commons. DOI: https://doi.org/10.31237/osf.io/e9fyu

Setiawan, Adib Rifqi; \& Ilmiyah, Surotul. (2020, April 13). Kecerdasan Majemuk Berdasarkan Neurosains. EdArXiv. DOI: https://doi.org/10.35542/osf.io/rj2fe

Setiawan, Adib Rifqi. (2020, April 9). Islamic Education in Southeast Asia. EdArXiv. DOI: https://doi.org/10.35542/osf.io/dnjqv

Ilmiyah, Surotul; \& Setiawan, Adib Rifqi. (2020, April 7). Students' Worksheet for Distance Learning Based on Scientific Literacy in the Topic Coronavirus Disease 2019 (COVID-19). Thesis Commons. DOI: https://doi.org/10.31237/osf.io/fpg4j

Ilmiyah, Surotul; \& Setiawan, Adib Rifqi. (2020, April 7). Students' Worksheet for Distance Learning Based on Scientific Literacy in the Topic Coronavirus Disease 2019 (COVID-19). EdArXiv. DOI: https://doi.org/10.35542/osf.io/wyz5v 
Setiawan, Adib Rifqi; \& Ilmiyah, Surotul. (2020, April 7). Lembar Kegiatan Siswa untuk Pembelajaran Jarak Jauh Berdasarkan Literasi Saintifik pada Topik Penyakit Coronavirus 2019 (COVID-19). EdArXiv. DOI: https://doi.org/10.35542/osf.io/h4632

Setiawan, Adib Rifqi. (2020, April 2). Desain Pembelajaran untuk Membimbing Siswa Sekolah Dasar dalam Memperoleh Literasi Saintifik. EdArXiv. DOI: https://doi.org/10.35542/osf.io/u59f8

Velasufah, Whasfi; \& Setiawan, Adib Rifqi. (2020, April 13). Nilai Pesantren Sebagai Dasar Pendidikan Karakter. Thesis Commons. DOI: https://doi.org/10.31237/osf.io/hq6kz

Setiawan, Adib Rifqi. (2020, April 9). Islamic Education in Southeast Asia. Thesis Commons. DOI: https://doi.org/10.31237/osf.io/e794d

Setiawan, Adib Rifqi. (2020, April 2). What is the Best Way to Analyze Pre-Post Data?. EdArXiv. DOI: https://doi.org/10.35542/osf.io/h4e6q

Setiawan, Adib Rifqi. (2020, April 4). Grace Natalie Louisa. SocArXiv. DOI: https://doi.org/10.31235/osf.io/zwf6g

Setiawan, Adib Rifqi. (2020, April 3). Sharifah Halimah Alaydrus : a female preachers for our time. SocArXiv. DOI: https://doi.org/10.31235/osf.io/zb8qe

Setiawan, Adib Rifqi. (2020, April 1). Syarifah Halimah Alaydrus. Thesis Commons. DOI: https://doi.org/10.31237/osf.io/xbmcs

Setiawan, Adib Rifqi. (2020, April 13). Commodification of the Sexuality in Kim Kardashian's Instagram Posts. Thesis Commons. URL: https://thesiscommons.org/mf7nw/

Setiawan, Adib Rifqi. (2020, April 5). The Arrogant One. Thesis Commons. DOI: https://doi.org/10.31237/osf.io/8nmku

Setiawan, Adib Rifqi. (2020, April 4). Grace Natalie Louisa. Thesis Commons. DOI: https://doi.org/10.31237/osf.io/u3mxv

Setiawan, Adib Rifqi. (2020, April 2). JUPE My Uncut Story. Open Science Framework (OSF). DOI: https://doi.org/10.31219/osf.io/qdxga

Setiawan, Adib Rifqi. (2020, April 1). Sharifah Halimah Alaydrus. Thesis Commons. DOI: https://doi.org/10.31237/osf.io/fp79c

Setiawan, Adib Rifqi. (2020, April 13). مبادئ اللغة العربية. Thesis Commons. DOI: https://doi.org/10.31237/osf.io/2gvjf 